\title{
Relationship between total antioxidant capacity and the severity of coronary artery disease
}

\author{
Total antioksidan kapasite ile koroner arter hastalığı şiddeti arasındaki ilişki \\ Murat Aydın' ${ }^{1}$, Yusuf Selcoki ${ }^{2}$, Yunus Nazlı ${ }^{3}$, Necmettin Çolak ${ }^{3}$, Kadir Serkan Yalçın ${ }^{4}$, Metin Canbal ${ }^{5}$, \\ Bora Demirçelik², Ramazan Yiğitoğlu ${ }^{1}$, Beyhan Eryonucu ${ }^{2}$ \\ ${ }^{1}$ Dept. Biochemistry, ${ }^{2}$ Dept. Cardiology, 3 Dept. Cardiovascular Surgery, \\ ${ }^{4}$ Dept. Internal Medicine, ${ }^{5}$ Dept. Family Medicine, Faculty of Medicine, Fatih University, Ankara, Turkey
}

\begin{abstract}
Objectives: It was known that oxidative/antioxidative balance shifted to oxidative side in patients with coronary artery disease. The aim of this study is to evaluate the relationship between coronary artery disease and total antioxidant status, oxidative stress index.
\end{abstract}

Materials and methods: The study group consisted of 87 consecutive patients who were hospitalized for coronary angiography. Plasma total oxidative status (TOS) and total antioxidative capacity (TAC) levels were measured and oxidative stress index (OSI) was calculated.

Results: The TAC values increased statistically significant in the four tertile compared with the first tertile (1.9 \pm 0.2 vs $2.0 \pm 0.2 \mathrm{mmol}$ Trolox $\mathrm{Eq} / \mathrm{l}$ ) and the TOS values decreased non- significantly in the four tertile ( $5.2 \pm 2.8$ vs $\left.7.2 \pm 5.4 \mu \mathrm{mol} \mathrm{H}_{2} \mathrm{O}_{2} \mathrm{Eq} / \mathrm{l}\right)$ as compared to the patients in the first tertile. According to the number of diseased vessels, plasma oxidative characteristics did not differ between the three groups.

Conclusions: Plasma TAC levels increased in subjects with coronary atherosclerosis and severity of coronary atherosclerosis is related with TAC. J Clin Exp Invest 2012; 3(1): 22-28

Key words: coronary artery disease; total antioxidant capacity; oxidative stress

\section{INTRODUCTION}

Cardiovascular disease is the leading cause of morbidity and mortality in industrialized countries. Reactive oxygen species (ROS) such as superoxide anion, hydrogen peroxide and hydroxyl radicals are produced during normal cellular function and their high chemical reactivity leads to the oxidation of lipids, proteins or DNA. The balance between ROS generation and antioxidant activity is critical to the

\section{ÖZET}

Amaç: Koroner arter hastalarında oksidatif/ antioksidatif dengenin oksidatif taraf lehine kaydığı bilinmektedir. Bu çalışmanın amacı, total antioksidan durum, oksidatif yük ve koroner arter hastalığı arasındaki ilişkiyi incelemektir.

Gereç ve yöntem: Çalışma grubu, koroner Anjiyografi yapmak için hastaneye yatırılan ardışık 87 hastadan oluşmaktadır. Plazma total oksidatif durum (TOD) ve total antioksidan kapasite (TAK) seviyeleri ölçüldü ve oksidatif stres indeksi (OSi) hesaplandı.

Bulgular: Dördüncü gruptaki TAK değerleri ilk grup (1.9 \pm 0.2 vs $2.0 \pm 0.2 \mathrm{mmol}$ Trolox Eq/l) ile karşılaştırıldığında istatistiksel olarak anlamlı derecede artmıştı ve birinci gruptaki hastalar ile karşılaştırıldığında, dördüncü gruptaki ( $5.2 \pm 2.8$ vs $7.2 \pm 5.4 \mu \mathrm{mol} \mathrm{H}_{2} \mathrm{O}_{2}$ Eq/I) TOD değerlerindeki azalma anlamlı değildi. Hastalıklı damar sayısına göre, plazma oksidatif özellikleri üç grup arasında farklı bulunmadı.

Sonuç: Plazma TAK düzeyleri koroner arter hastalığı olan kişilerde artmıştır ve koroner aterosklerozun ağırlığı TAK ile ilişkilidir.

Anahtar kelimeler: Koroner arter hastalığı, total antioksidan kapasite, oksidatif yük

pathogenesis of oxidative stress-related disorders. ${ }^{1}$ Oxidative stress to lipids and DNA caused by free radicals are known to be one of the several fundamental biological mechanisms that are responsible for developing atherosclerosis. ${ }^{2,3}$

Oxidants were increased and antioxidants were decreased, and because of these, oxidative/antioxidative balance shifted to oxidative side in patients with coronary artery disease (CAD). ${ }^{4}$ Antioxidants 
have been hypothesized to inhibit lipid peroxidation and therefore may play a protective role in the development of cardiovascular disease by preventing the formation of early atherosclerotic lesions. ${ }^{5}$

Plasma concentrations of antioxidants can be measured separately in laboratory, but these measurements are time-consuming, labor-intensive, and costly. Therefore, several methods have been developed to determine the antioxidative capacity of various biological samples. ${ }^{6}$ Since antioxidative effects of antioxidant components of plasma are additive, the measurement of total antioxidant capacity (TAC) can reflects the antioxidative status of plasma. ${ }^{7,8}$ Individual metabolites may not necessarily reflect the whole condition. Therefore, when seeking a specific relationship between oxidative metabolism and suggested diseases, an evaluation of total antioxidant-oxidant capacity is essential.

Previous studies showed that the plasma TAC was significantly reduced in patients with $C A D$ as compared with healthy subjects. ${ }^{9,10}$ In the present study, we aimed to investigate the oxidative/ antioxidative status in patients with CAD and their relationships with the extent of CAD according to Gensini score.

\section{MATERIALS AND METHODS}

The study was conducted at the Departments of Cardiology and Clinical Biochemistry. Eighty-seven patients with angiographically demonstrated coronary vessel status were evaluated for this study. Informed consent for participation in the study was obtained from all patients. Institutional ethics committee approval was obtained. Past medical history, habitual status and current medications were recorded.

Exclusion criteria were heart failure, immunological disease, metabolic disease, history or presence of neoplastic disease, liver and kidney disease, age over 70 years, acute and chronic inflammatory disease, diabetes mellitus and recent major surgical procedure. None of the patients was taking antioxidant drug therapy.

The patients who had total cholesterol level of $>220 \mathrm{mg} / \mathrm{dl}$ or triglyceride concentration $>200 \mathrm{mg} /$ $\mathrm{dl}$, or receiving lipid-lowering drugs were defined as having hyperlipidemia. Hypertension was defined as a diastolic blood pressure $\geq 90 \mathrm{mmHg}$, systolic blood pressure $\geq 140 \mathrm{mmHg}$ or self-reported use of an antihypertensive drug. Smokers were defined as those who had been smoking regularly (smoking daily for at least 1 year) until admission.
All patients in the study underwent selective coronary angiography (Philips Allura Xper FD10) after appropriate patient preparation. Angiograms were performed for the investigation of ischaemic heart disease based on clinical indications (typical and atypical chest discomfort or abnormal stress test result). Two experienced cardiologists, blind to the patients' clinical characteristics and biochemical results, reviewed all the angiographic images.

The severity of coronary artery stenosis was assessed and classified according to the American Heart Association System. ${ }^{11}$ The percentage stenosis of the coronary artery was determined by handheld calliper measurement. Significant angiographic coronary stenosis was defined as the presence of stenosis $>70 \%$ of the luminal diameter. Multivessel disease (VD) was defined as the presence of significant stenosis in more than one of the three major epicardial coronary arteries. The presence of stenosis in the left main coronary artery with $>50 \%$ luminal diameter was also considered to be multivessel disease.

The Gensini score was calculated for each patient from the coronary arteriogram and was computed by assigning a severity value to each coronary stenosis according to the degree of luminal narrowing and its locational importance. Reduction in the lumen diameter and the roentgenographic appearance of concentric lesions and eccentric plaques were evaluated (reductions of $25 \%, 50 \%$, $75 \%, 90 \%, 99 \%$ and complete occlusion were given Gensini scores of 1, 2, 4, 8, 16, and 32, respectively). The score was then multiplied by a factor relative to the importance of the lesion's location in the coronary arterial tree: for example, 5 for left main coronary artery, $\mathbf{2 . 5}$ for proximal left anterior descending coronary artery and proximal left circumflex coronary artery $(3.5$ if left circumflex coronary artery is dominant), 1.5 for mid-region of the left anterior descending coronary artery; 1 for distal left anterior descending coronary artery, the first diagonal, the proximal, mid- and distal-region of the right coronary artery, the postero-descending, the mid and distal-region of the left circumflex coronary artery ( 2 for both of them if left circumflex coronary artery is dominant) and the obtus margin, and 0.5 for the second diagonal and the postero-lateral branch. $^{12}$

Blood samples were obtained following an overnight fasting state before coronary angiography. Samples were withdrawn from a cubital vein into blood tubes and stored at $-80{ }^{\circ} \mathrm{C}$. The serum was separated from the cells by centrifugation at $3.000 \mathrm{rpm}$ for $10 \mathrm{~min}$ and then analyzed. 
Total oxidant status of plasma was measured using a novel automated colorimetric measurement method for TOS developed by Erel. ${ }^{8}$ In this method oxidants present in the sample oxidize the ferrous ion-o-dianisidine complex to ferric ion. The oxidation reaction is enhanced by glycerol molecules, which are abundantly present in the reaction medium. The ferric ion makes a colored complex with xylenol orange in an acidic medium. The color intensity, which can be measured spectrophotometrically, is related to the total amount of oxidant molecules present in the sample. The assay is calibrated with hydrogen peroxide and the results are expressed in terms of micromolar hydrogen peroxide equivalent per liter ( $\left.\mu \mathrm{mol} \mathrm{H}_{2} \mathrm{O}_{2} \mathrm{Eq} / \mathrm{l}\right)$.

Total antioxidant capacity of plasma was measured using a novel automated colorimetric measurement method for TAC developed by Erel. ${ }^{7}$ In this method, the hydroxyl radical, the most potent biological radical, is produced by the Fenton reaction and it reacts with the colorless substrate O-dianisidine to produce the dianisyl radical, which is bright yellowish-brown in color. Upon the addition of a plasma sample, the oxidative reactions initiated by the hydroxyl radicals present in the reaction are suppressed by the antioxidant components of the plasma, preventing the color change and thereby providing an effective measurement of TAC. The assay results were expressed as mmol Trolox Eq/l, and the precision of this assay is excellent, being lower than $3 \%$.

The ratio of TOS to TAC was accepted as the oxidative stress index (OSI). For calculation, the resulting unit of TAC was converted to $\mathrm{mmol} / \mathrm{l}$, and the OSI value was calculated according to the following formula: OSI (arbitrary unit) $=$ TOS $\left(\mu \mathrm{mol} \mathrm{H}_{2} \mathrm{O}_{2} \mathrm{Eq} / \mathrm{l}\right)$ / TAC (mmol Trolox Eq/l). ${ }^{13}$

\section{Statistical analysis}

Results were expressed as mean \pm S.D. or median (range) values for all continuous variables. Differences subjects were assessed using the Student's t-tests and chi-square test. Associations between severity of coronary atherosclerosis, TAC and other variables were evaluated by Pearson's correlation test. The independence of these associations was evaluated by multiple linear regression analysis. Patients were grouped according to severity of coronary atherosclerosis involved, and comparisons among the groups were performed by using ANOVA test. A $p<0.05$ was considered statistically significant. Analysis was done with SPSS 11.0 statistical software.

\section{RESULTS}

Clinical characteristics of patients are presented in Table1. The mean age in the study group was $43.5 \pm 10.9$ years, $63 \%$ were men, $59 \%$ were hypertensive, $13 \%$ were smokers. Mean Gensini score, mean plasma levels of TAC, TOS, OSI, total cholesterol, LDL cholesterol, HDL cholesterol and triglycerides are reported in Table 1.

Table 1. Baseline demographic, laboratory and treatment data characteristics

\begin{tabular}{ll}
\hline & Mean value \\
\hline Age (years) & $43.5 \pm 10.9$ \\
Gender (male, \%) & $63 \%$ \\
Total cholesterol (mg/dl) & $194.8 \pm 40(69-289)$ \\
LDL cholesterol (mg/dl) & $120.9 \pm 35.1(31-214)$ \\
HDL cholesterol $(\mathrm{mg} / \mathrm{dl})$ & $40.9 \pm 11.7(19-91)$ \\
Triglyceride $(\mathrm{mg} / \mathrm{dl})$ & $164 \pm 96(57-556)$ \\
Gensini Score & $31 \pm 40(0-159)$ \\
TAC (mmol Trolox equivalent/l) & $2.0 \pm 0.2(1.47-2.6)$ \\
TOS $\left(\mu \mathrm{mol} \mathrm{H}_{2} \mathrm{O}_{2}\right.$ eq/l) & $6.6 \pm 4.0(4.7-28.4)$ \\
OSI $($ AU) & $0.33 \pm 0.1(0.09-1.2)$ \\
ACE inhibitor $(\mathrm{n})$ & 21 \\
ARB $(\mathrm{n})$ & 17 \\
Beta blocker $(\mathrm{n})$ & 30 \\
Calcium channel blockers $(\mathrm{n})$ & 17 \\
Diuretics $(\mathrm{n})$ & 19 \\
Statins $(\mathrm{n})$ & 18 \\
Smoking, \% & 13 \\
\hline
\end{tabular}

TAC, total antioxidant capacity; TOS, total oxidative status; OSI, oxidative stress index; ACE, angiotensin-converting enzyme inhibitors; ARB, angiotensin receptor blocker

We divided the patients in four subgroups according to quartiles of Gensini score level. The demographic, biological and treatment characteristic of the four subgroups according to Gensini quartiles are depicted in Table 2.

There was statistically significantly higher incidence of hypertension in the four tertile compared with the first tertile of Gensini score ( $p$ for trend = 0.001 ). The use of betablockers, statine and angiotensin converting enzime inhibitors was also statistically significantly higher in the four tertile compared 
with the first tertile of Gensini score ( $p$ for trend were $0.0001,0.0001$ and 0.01 respectively).

As regards the lipid profile, the mean values of total cholesterol, LDL cholesterol and triglycerides did not differ significantly between subgroups. HDL cholesterol values decreased in the four tertile ( $37 \pm 11 ; 40 \pm 10, p$ for trend $=0.02$ ) as compared to the patients in the first tertile.

Across the Gensini quartiles the TAC values increased statistically significant in the four tertile compared with the first tertile $(1.9 \pm 0.2$ vs $2.0 \pm$ $0.2 \mathrm{mmol}$ Trolox Eq/l; $p$ for trend $=0.03$ ) and the TOS values decreased non- significantly in the four tertile ( $5.2 \pm 2.8$ vs $7.2 \pm 5.4 \mu \mathrm{mol} \mathrm{H}_{2} \mathrm{O}_{2} \mathrm{Eq} / \mathrm{l} ; \mathrm{p}$ for trend $=0.13$ ) as compared to the patients in the first tertile. As regards the OSI, did not differ significantly between Gensini subgroups. ( $p$ for trend $=0.09$ ).

The correlations between Gensini score and oxidative characteristics are listed in Table 3. A significant positive correlation was found between
Gensini score and TAC, presence of hypertension $(r=0.243, p=0.023),(r=0.30, P=0.005)$ and significant negative correlation with OSI $(r=-0.234, p$ $=0.02$ ). In multiple linear regression analysis, presence of hypertension (Beta $=0.4 ; p=0.03$ ) were the only statistically significant independent predictors that correlated with the Gensini score values Table 4.

Comparisons of variables according to number of significant coronary stenosis vessels are investigated. Patients with CAD divided into three categories according to the number of diseased vessels: one-VD (16), two-VD (13), and three-VD (11). Slight increased TAC was observed in the three-VD compared with the two-VD and one-VD categories but this difference was not statistically significant $(2.15 \pm 0.2,2.03 \pm 0.2$ and $2.01 \pm 0.2, p>0.05)$. Also, the slight decrease in TOS and OSI was observed in the three-VD category but this difference was not statistically significant $(6.7 \pm 3.4,6.4 \pm 4.2,5.4 \pm 2.8$ and $0.33 \pm 0.1,0.32 \pm 0.2,0.24 \pm 0.1 p>0.05$ ).

Table2. Demographic, laboratory and treatment data in the four Gensini score tertiles

\begin{tabular}{|c|c|c|c|c|c|}
\hline Gensini tertile & $\begin{array}{l}1^{\text {st }} \text { Tertile } \\
(n=22)\end{array}$ & $\begin{array}{l}2^{\text {nd }} \text { Tertile } \\
(n=20)\end{array}$ & $\begin{array}{l}3^{\text {rd }} \text { Tertile } \\
(n=25)\end{array}$ & $\begin{array}{l}4^{\text {rd }} \text { Tertile } \\
(n=20)\end{array}$ & $P$ for trend \\
\hline Age (years) & $44.7 \pm 10.7$ & $43.7 \pm 11.4$ & $42.2 \pm 10.6$ & $43.6 \pm 10.6$ & \\
\hline Gender (male; female) & $8 / 14$ & $13 / 7$ & $17 / 8$ & $17 / 3$ & \\
\hline Total cholesterol (mg/dl) & $201 \pm 30.0$ & $180 \pm 27$ & $199 \pm 40$ & $196 \pm 54$ & 0.3 \\
\hline LDL cholesterol (mg/dl) & $126 \pm 35$ & $114 \pm 26$ & $118 \pm 32$ & $125 \pm 45$ & 0.3 \\
\hline HDL cholesterol (mg/dl) & $44 \pm 10$ & $37 \pm 10$ & $44 \pm 13$ & $37 \pm 11$ & 0.02 \\
\hline Triglyceride (mg/dl) & $149 \pm 114$ & $146 \pm 71$ & $179 \pm 89$ & $176 \pm 111$ & 0.2 \\
\hline TAC (mmol Trolox equivalent/l) & $1.9 \pm 0.2$ & $1.9 \pm 0.2$ & $2.07 \pm 0.2$ & $2.0 \pm 0.2$ & 0.03 \\
\hline $\operatorname{TOS}\left(\mu \mathrm{mol} \mathrm{H}_{2} \mathrm{O}_{2} \mathrm{eq} / \mathrm{l}\right)$ & $7.2 \pm 5.4$ & $6.1 \pm 2.8$ & $7.6 \pm 3.9$ & $5.2 \pm 2.8$ & 0.139 \\
\hline OSI (AU) & $0.36 \pm 0.24$ & $0.32 \pm 0.13$ & $0.36 \pm 0.18$ & $0.33 \pm 0.18$ & 0.09 \\
\hline ACE inhibitor, $\%$ & 4.5 & 15 & 36 & 42.1 & 0.01 \\
\hline $\mathrm{ARB}, \%$ & 22.7 & 15 & 24 & 15.8 & 0.8 \\
\hline Beta blocker, \% & 4.5 & 20 & 52.0 & 63 & 0.001 \\
\hline Calcium channel Blockers, \% & 9.1 & 15.0 & 32 & 21.1 & 0.24 \\
\hline Diuretics, \% & 13.6 & 15 & 24 & 36.8 & 0.27 \\
\hline Statins, $\%$ & 0 & 0 & 36 & 47.4 & 0.001 \\
\hline Hypertension, \% & 27.3 & 55 & 76 & 84.2 & 0.001 \\
\hline Smoking, \% & 21.4 & 26.7 & 11.8 & 20 & 0.76 \\
\hline
\end{tabular}

TAC, total antioxidant capacity; TOS, total oxidative status; OSI, oxidative stress index; LDL cholesterol - low density lipoprotein cholesterol; HDL cholesterol - high density lipoprotein cholesterol; ACE - angiotensin conversion enzyme; ARB - angiotensin receptor blockers. 
Table 3. Correlations between the Gensini score, TAC, TOS, OSI, Hypertension, LDL cholesterol, smoking

\begin{tabular}{lccccccc}
\hline $\begin{array}{l}\text { Gensini } \\
\text { score }\end{array}$ & $\begin{array}{c}\text { TAC }(\mathrm{mmol} \text { Trolox } \\
\text { equivalent/l) }\end{array}$ & $\begin{array}{c}\mathrm{TOS}\left(\mu \mathrm{mol} \mathrm{H}_{2} \mathrm{O}_{2}\right. \\
\text { eq/l) }\end{array}$ & $\begin{array}{c}\text { OSI } \\
(\mathrm{AU})\end{array}$ & Hypertension & $\begin{array}{c}\text { LDL cholesterol } \\
(\mathrm{mg} / \mathrm{dl})\end{array}$ & Smoking & $\begin{array}{c}\text { Total cholesterol } \\
(\mathrm{mg} / \mathrm{dl})\end{array}$ \\
\hline $\mathrm{r}$ & 0.243 & -0.17 & -0.234 & 0.30 & -0.026 & -0.001 & -0.06 \\
$\mathrm{P}$ & 0.023 & 0.10 & 0.02 & 0.005 & 0.8 & 0.9 & 0.56 \\
\hline
\end{tabular}

TAC, total antioxidant capacity; TOS, total oxidative status; OSI, oxidative stress index; LDL cholesterol - low density lipoprotein cholesterol

Table 4. Multivariate regression analysis for the Gensini score. Model summary

\begin{tabular}{ccccc}
\hline Model & $\mathrm{R}$ & $\mathrm{R}$ Square & Adjusted R Square & $\begin{array}{c}\text { Sig. } \\
\text { (2-tailed) }\end{array}$ \\
0.64 & 0.42 & 0.14 & 0.18 \\
\hline
\end{tabular}

Multivariate analysis

\begin{tabular}{lll}
\hline & Beta & Sig (2 tailed) \\
\hline (Constant) & & \\
TAC $(\mathrm{mmol}$ Trolox equivalent/l) & 0.000 & 0.9 \\
TOS $\left(\mu \mathrm{mol} \mathrm{H}_{2} \mathrm{O}_{2}\right.$ eq/l) & -0.19 & 0.9 \\
OSI $(\mathrm{AU})$ & -0.22 & 0.8 \\
Hypertension & 0.4 & 0.03 \\
Total cholesterol $(\mathrm{mg} / \mathrm{dl})$ & -14.4 & 0.2 \\
HDL cholesterol $(\mathrm{mg} / \mathrm{dl})$ & 13.0 & 0.2 \\
Smoking & 0.11 & 0.5 \\
\hline
\end{tabular}

TAC, total antioxidant capacity; TOS, total oxidative status; OSI, oxidative stress index; HDL cholesterol - high density lipoprotein cholesterol; $\mathrm{Cl}$, Confidence Interval

\section{DISCUSSION}

The present study investigated plasma oxidative stres markers, TAC, TOS and OSI. We report for the first time a significant association between elevated levels of TAC, lower OSI and increased coronary artery lesions objectively assessed by coronary angiography.

These factors were not shown to be independently associated in multivariate analysis with the Gensini score. The slight increase in TAC and the slight decrease OSI was observed in the three-VD group.

In the literature there are various outcomes about antioxidan and TAC levels in diverse studies. A number of report in the literature implicate excessive oxidative stress and/or inadequate antioxidant defences in the pathogenesis of cardiovascular risk and disease. ${ }^{14,15}$ In addition to traditional risk factors, oxidative stress and lipid peroxidation are involved in the pathogenesis of atherosclerosis. ${ }^{16}$ There are encouraging correlation between DNA oxidation and TAC in smokers, however plasma TAC in smokers imprecisely higher than nonsmokers. ${ }^{17}$ Oxidative stress induces macrophage responses such as increased capacity to oxidize LDL, increased oxidized-LDL celluler uptake, as well as macrophage lipid peroxidation and increased intimal accumulation of smooth muscle cells. ${ }^{18}$ Regnström et al. ${ }^{19}$ described an inverse association between resistance of LDL to oxidation and severity of coronary stenosis in patients; however, the study of Croft et al. ${ }^{20}$ did not reveal a difference in oxidation parameters between coronary atherosclerotic patients and control subjects. On the other hand as a consequence of using lipid-lowering therapy (Atorvastatin $10 \mathrm{mg} / \mathrm{kg}$ ), $\% 7.6$ elevated TAC plasma levels were achieved. ${ }^{21}$ Plasma OSI, the ratio of total plasma TOS level to TAC, is an indicator of oxidative stress, reflecting the redox balance between oxidation and antioxidation. ${ }^{8,13}$ We demonstrated that an inverse association between oxidative parameters (TOS, OSI) and the extent coronary artery disease but the association is statistically non-significantly.

It is well-known that various antioxidants in plasma have an additive effect, protecting the organism from fee radicals. ${ }^{22}$ In this respect, measurement of TAC provides information about the antioxidant capacity of organism. ${ }^{7}$ Previous studies showed that plasma antioxidant capacity was significantly reduced in patients with CAD. Demirbag et al. ${ }^{10}$ showed that TAC is decreased and DNA damage is increased in CAD patients compared with normal subjects. The DNA damage is negatively correlated wit TAC and it is positively correlated with severity of CAD. In another study, Demirbag et al. ${ }^{23}$ found a strong correlation between the TAC level and severity of aortic atherosclerosis. Unlike, our results showed that TAC levels increased in subjects with coronary atherosclerosis and severity of coronary atherosclerosis is positively related with TAC.

Many studies have investigated by what mechanisms the endogenous antioxidants in plasma and LDL inhibit lipid peroxidation and oxidation of LDL. 
These studies have focused mainly on vitamin C, vitamin $\mathrm{E}$ and carotenoids. Jialal et al. indicated that combined supplementation with antioxidants resulted in a significant inhibition of LDL oxidation. These findings also point to the significance of administration of antioxidant therapy for the managent of CAD. ${ }^{2,24,25}$

Raising TAC levels of plasma accompanying low blood pressure and low lipid peroxidation in obese patients could be acquired through by DASH diet. ${ }^{15}$ Despite the conflicting results in CAD, negative correlation only with TAC and the number of injured vessels was widely recognized.

Physical activity is known to have beneficial health effects in patients with CAD. Many studies reported that fat soluble plasma antioxidants increase after aerobic exercise and isometric exercise in humans. ${ }^{26}$ Increasing TAC levels in our study may be due to intake dietary antioxidant nutrients and regular exercising.

Our findings can be explained with following possible mechanisms: (1) alteration of oxidant/antioxidant balance on behalf of antioxidant capacity as a defensive process in patients with CAD, (2) use of agents with anti-oxidative effects such as ACE inhibitors and statins in patients with severe CAD. (3) as a part of antioxidant defensive mechanisms it may increase involved in oxidative stress or some other pathologies like smoking or CAD.

In conclusion, plasma TAC levels increased in subjects with coronary atherosclerosis and severity of coronary atherosclerosis is related with TAC.

\section{REFERENCES}

1. Devasagayam TP, Tilak JC, Boloor KK, Sane KS, Ghaskadbi SS, Lele RD. Free radicals and antioxidants in human health: current status and future prospects. J Assoc Physicians India 2004; 52(1): 94-9.

2. Serdar Z, Aslan K, Dirican M, Sarandöl E, Yesilbursa D, Serdar A. Lipid and protein oxidation and antioxidant status in patients with angiographically proven coronary artery disease. Clin Biochem 2006; 39(8):794803.

3. Bridges BA, Bowyer DE, Hansen ES, Penn A, Wakabayashi $\mathrm{K}$. The possible involvement of somatic mutations in the development of atherosclerotic plaques. Mutat Res 1990;239 (3):143-8.

4. Nojiri S. Daida H, Mokuno $H$, et al. Association of serum antioxidant capacity with coronary artery disease in middle-aged men. Jpn Heart J 2001; 42 (6):677-90.

5. Schwenke DC. Antioxidants and atherogenesis. J Nutr Biochem 1998;9: 424-45.

6. Yeum KJ, Russell RM, Krinsky NI, Aldini G. Biomarkers of antioxidant capacity in the hydrophilic and lipophilic compartments of human plasma. Arch Biochem Biophys 2004;430 (1):97-103.

7. Erel O. A novel automated method to measure total antioxidant response against potent free radical reactions. Clin Biochem 2004;37(2):112-9.

8. Erel O. A new automated colorimetric method for measuring total oxidant status. Clin Biochem 2005;38(12):1103-11.

9. Gur M, Aslan M, Yildiz A, et al. Paraoxonase and arylesterase activities in coronary artery disease. Eur J Clin Invest 2006; 36(11):779-87.

10. Demirbag R, Yilmaz R, Kocyigit A. Relationship between DNA damage, total antioxidant capacity and coronary artery disease. Mutat Res 2005; 570(2):197203.

11. Austen WG, Edwards JE, Frye RL, et al. A reporting system on patients evaluated for coronary artery disease. Report of the Ad Hoc Committee for Grading of Coronary Artery Disease, Council on Cardiovascular Surgery, American Heart Association. Circulation 1975;51(4 Suppl):5-40.

12. Gensini GG. A more meaningful scoring system for determining the severity of coronary heart disease. Am J Cardiol 1983;51(3):606-7.

13. Demirbag R, Gur M, Yilmaz R, Kunt AS, Erel O, Andac $\mathrm{MH}$. Influence of oxidative stress on the development of collateral circulation in total coronary occlusions. Int J Cardiol 2007;116(1):14-9.

14. Young IS, Woodside JV. Antioxidants in health and disease. J Clin Pathol 2001;54(3): 176-86.

15. Lopes HF, Martin KL, Nashar K, Morrow JD, Goodfriend TL, Egan BM. DASH diet lowers blood pressure and lipid-induced oxidative stress in obesity. Hypertension 2003;41(3):422-30.

16. Casalone R, Granata P, Minelli E, et al. Cytogenic analysis reveals clonal proliferation of smooth muscle cells in atherosclerotic plaques. Hum Genet 1991;87(2):139-43.

17. Nia $A B$, van schooten FJ, Schilderman PAEL, et al. A multi-biomarker approach to study the effects of smoking on oxidative DNA damage and repair and antioxidative defense mechanisms. Carcinogenesis 2001;22(3):395-401.

18. Fuhrman B, Rosenblat M, Hayek T, Coleman R, Aviram $M$. Ginger extract consumption reduces plasma cholesterol, inhibits LDL oxidation and attenuates development of atherosclerosis in atherosclerotic, apolipoprotein E-deficient mice. J Nutr 2000;130(5):112431.

19. Regnström J, Nilsson J, Tornvall P, Landou C, Hamsten A. Susceptibility to low density lipoprotein oxidation and coronary atherosclerosis in man. Lancet 1992;339(8803):1183-6.

20. Croft KD, Dimmitt SB, Moulton C, Beilin LJ. Low density lipoprotein composition and oxidizability in coronary disease-apparent favourable effect of beta blockers. Atherosclerosis 1992;97(2-3):123-30. 
21. Orem C, Orem A, Uydu HA, Celik S, Erdol C, Kural $B V$. The effects of lipid-lowering therapy on low-density lipoprotein autoantibodies: relationship with lowdensity lipoprotein oxidation and plasma total antioxidant status. Coron Artery Dis. 2002:13(1):65-71.

22. Wayner DD, Burton GW, Ingold KU, Barclay LR, Locke SJ. The relative contributions of vitamin $E$, urate, ascorbate and proteins to the total peroxyl radical-trapping antioxidant activity of human blood plasma. Biochim Biophys Acta 1987;924(3):408-19.

23. Demirbag R, Yilmaz R, Kunt AS, Gur M, Ulucay A, Unlu D. Relation between plasma total anti-oxidant capacity and thoracic aortic intima-media thickness. Echocardiography 2006;23(3):183-88.

24. Gokce N, Frei B. Basic research in antioxidant inhibition of steps in atherogenesis. J Cardiovasc Risk 1996;3(4):352-7.

25. Jialal I, Grundy SM. Effect of combinated supplementation wit $\alpha$-tocopherol, ascorbate, and $\beta$ carotene on low-density lipoprotein oxidation. Circulation 1993;88(6):2780-6.

26. Alessio HM, Hagerman AE, Fulkerson BK, Ambrose J, Rice RE, Wiley RL. Generation of reactive oxygen species after exhaustive aerobic and isometric exercise. Med Sci Sports Exerc 2000;32(9):1576-81. 